\author{
Bożena Wójtowicz \\ Uniwersytet Pedagogiczny \\ im. Komisji Edukacji Narodowej \\ w Krakowie
}

\title{
Postawy i umiejętności interpersonalne studentów wobec roli przedsiębiorczości w warunkach gospodarki rynkowej
}

\author{
Students' interpersonal skills and attitudes towards the role of entrepreneurship \\ in the market economy
}

\begin{abstract}
Streszczenie
Ważną rolę we współczesnym świecie odgrywa gospodarka rynkowa, w której decyzje dotyczące zakresu i sposobu produkcji podejmowane są przez podmioty gospodarcze (gospodarstwa domowe, gospodarstwa rolne, instytucje finansowe, rząd), kierujące się własnym interesem i postępujące zgodnie z zasadami racjonalności gospodarowania. Przedsiębiorczość należy do istotnych właściwości ludzi, którzy żyją i gospodarują w świecie, w warunkach gospodarki rynkowej. We współczesnym świecie działalność gospodarcza, polegająca na produkcji i wymianie, prowadzona jest przez wiele podmiotów konkurujących ze sobą. Skoro zmienia się gospodarka, zmieniają się również cechy potrzebne do przetrwania w niej, nie mówiąc już o odnoszeniu sukcesów. Podstawą do przygotowania oraz podejmowania decyzji o zasadach, kierunkach i tempie perspektywicznego rozwoju kształcenia z zakresu przedsiębiorczości w warunkach gospodarki rynkowej było przeprowadzenie badań diagnostycznych wśród studentów. Na ich podstawie stwierdzono, że istnieją braki wiedzy z zakresu przedsiębiorczości w warunkach gospodarki rynkowej. Wybranie społeczeństwa młodego jako grupy docelowej uzasadnione jest rolą, którą odgrywa w życiu społecznym, a więc także w procesie budowania społeczeństwa przedsiębiorczego i innowacyjnego.
\end{abstract}

\begin{abstract}
The market economy plays an important role in the modern world, i.e. the market economy in which decisions regarding the scope and method of the production are made by the economy entities (house-holds, farms, financial institutions, government) and which are guided by the so-called self-interest and act according to the principles of the rationality in the management. 'Enterprising' is one of the essential characteristics of the people who live and manage in the world, in the conditions of the market economy. In today's world, the economy entity involving the production and the exchange is run by a number of entities competing with one another. Therefore, if the economy changes the qualities needed to survive in it must also change, not to mention the changes in the sphere of the abilities of being successful. The basis for the preparation and decision-making about the principles, directions and pace of the long-term development of education dealing with entrepreneurship in the market economy was created due to the conducted diagnostic research among students. The results of which showed that there was the sufficient lack of knowledge in the field of entrepreneurship in the market economy. Choosing the young population as the target group for the investigation is justified by the role it plays in the society, and therefore, in the process of creating the entrepreneurial and innovative society.
\end{abstract}

Słowa kluczowe: gospodarka rynkowa; innowacja; postawa przedsiębiorcza; przedsiębiorczość Key words: market economy; innovation; entrepreneurial attitude; entrepreneurship 


\section{Wstęp}

Przedsiębiorczość należy do istotnych właściwości ludzi, którzy żyją i gospodarują w świecie, w warunkach gospodarki rynkowej. We współczesnym świecie działalność gospodarcza, polegająca na produkcji i wymianie, prowadzona jest przez wiele podmiotów konkurujących ze sobą. Skoro zmienia się gospodarka, zmieniają się również cechy potrzebne do przetrwania w niej, nie mówiąc już o odnoszeniu sukcesów (Goleman, 1997). Nacisk ze strony konkurencji każe docenić ludzi, którzy potrafią się sami motywować do działania, wykazują inicjatywę, odczuwają wewnętrzną potrzebę prześcigania samych siebie i mają tyle optymizmu, że nie zniechęcają się niepowodzeniami czy porażkami, lecz uporczywie dążą do celu (Stanford, 2008). Wspólnota Europejska, mimo kryzysu gospodarczego, dalej się rozwija i osiąga sukcesy na wielu płaszczyznach, takich jak: płaszczyzna gospodarcza, społeczna, prawna, polityczna i edukacyjna. Państwa wysoko rozwinięte gospodarczo mają kilka celów, m.in. promocję ekonomicznego i społecznego postępu, polepszenie i powiększenie standardów życia oraz stworzenie jednej olbrzymiej struktury gospodarczej przez zacieśnianie współpracy. Taka gospodarka wymaga od ludzi dużej przedsiębiorczości. Szczególnie przedsiębiorcze powinny być działania człowieka związane z jego życiem codziennym we własnym gospodarstwie domowym oraz w działalności gospodarczej, zarówno w charakterze pracownika na różnych stanowiskach, jak i w charakterze przedsiębiorcy. W sferze gospodarczej przedsiębiorczość pozwala na podjęcie i prowadzenie działalności lub na twórcze w niej uczestniczenie. To ludzie przedsiębiorczy podejmują i rozwijają działalność gospodarczą, a także wyróżniają się sukcesami (Wójtowicz, 2011).

Ważną rolę we współczesnym świecie odgrywa gospodarka rynkowa, w której decyzje dotyczące zakresu i sposobu produkcji podejmowane są przez podmioty gospodarcze (gospodarstwa domowe, gospodarstwa rolne, instytucje finansowe, rząd), kierujące się własnym interesem i postępujące zgodnie z zasadami racjonalności gospodarowania. Podstawą podejmowania tych decyzji są informacje płynące z rynku, m.in.: ceny dóbr i usług, ceny czynników wytwórczych, płace, stopy bezrobocia, stopy zysku, kursy papierów wartościowych, kursy walutowe oraz oczekiwania podmiotów gospodarczych co do kształtowania się wyżej wymienionych w przyszłości (Stanford, 2008).

\section{Gospodarka rynkowa a przedsiębiorczość}

Gospodarka rynkowa to gospodarka, w której zasadniczym regulatorem procesów gospodarczych jest samoczynnie działający rynek czy też mechanizm rynkowy. Gospodarka rynkowa to taki typ organizacji człowieka, w którym koordynatorem procesów jest rynek, a własność czynników produkcji ma charakter prywatny. Z punktu widzenia działalności gospodarczej można wyodrębnić np. gospodarkę narodową, terenową, gospodarkę przedsiębiorstw, natomiast z punktu widzenia sfery gospodarowania - gospodarkę mieszkaniową, finansową, rolną, itp. Na podstawie kryterium własności czynników produkcji wyróżnia się w ramach danego kraju gospodarkę prywatną i publiczną, a w skali międzynarodowej: gospodarkę kapitalistyczną i socjalistyczną (komunistyczną). Gospodarka rynkowa, z którą związane są badania diagnostyczne, charakteryzuje się dwiema zasadniczymi cechami: dominacją prywatnej własności czynników produkcji oraz rynkową alokacją zasobów gospodarczych (http:/ makroekonomia.wiedza.daboli.pl/gospodarka-rynkowa/). Gospodarka rynkowa swoją nazwę zawdzięcza przede wszystkim temu, że podstawowym regulatorem i koordynatorem procesów gospodarczych jest w niej rynek, dlatego tak istotnym w kształceniu współczesnych pokoleń jest przygotowanie ich do pracy w gospodarce rynkowej.

Wzrost świadomości społecznej oraz postęp techniczny są możliwe dzięki ludzkim działaniom, których celem jest zaspokajanie rosnących potrzeb przy ograniczonych zasobach Ziemi. 
Współczesna gospodarka rynkowa szczególnie potrzebuje ludzi przedsiębiorczych, ze względu na dużą konkurencję na rynku oraz stały postęp techniczny, organizacyjny i ekonomiczny. Przedsiębiorczość zwykle utożsamiana jest z dużą aktywnością, zaradnością, bystrością oraz systematycznością, a także pomysłowością. Przedsiębiorczość jest „specyficzną postawą człowieka wobec otaczającego go świata i ludzi, wyrażającą się w twórczym i aktywnym dążeniu do ulepszania istniejących stanów rzeczy, w gotowości do podejmowania nowych działań lub rozszerzania dotychczasowych i dążenia do osiągania złożonych - zwykle zwiększonych - korzyści materialnych, które prowadzą do odczuwalnego wzrostu uzyskiwanych zysków (dochodów) oraz poprawy warunków życia i pracy" (Wiatrak, 2003, s. 26). Według Komisji Europejskiej „Przedsiębiorczość oznacza zdolność osoby do wcielania pomysłów w czyn. Obejmuje ona twórczość, innowacyjność i podejmowanie ryzyka, a także zdolność do planowania przedsięwzięć i kierowania nimi dla osiągnięcia zamierzonych celów. Stanowi ona wsparcie dla wszystkich w codziennym życiu prywatnym i społecznym, zaś pracownikom pomaga uzyskać świadomość kontekstu ich pracy i zdolność wykorzystywania szans; jest podstawą bardziej konkretnych umiejętności i wiedzy potrzebnych osobom podejmującym przedsięwzięcia o charakterze społecznym lub komercyjnym” (Komunikat Komisji dla Rady, Parlamentu Europejskiego, 2006: 5).

Zasadne jest więc pytanie o oczekiwania studentów oraz o ich umiejętności interpersonalne wobec roli przedsiębiorczości w zachodzących przemianach społeczno-gospodarczych w warunkach gospodarki rynkowej.

\section{Przedmiot, cele i metody badań}

Przedmiotem badań był aktualny poziom wiedzy i umiejętności z zakresu przedsiębiorczości na rzecz społeczeństwa innowacyjnego w warunkach gospodarki rynkowej, kształconych na studiach geograficznych na dwóch uczelniach: UP w Krakowie i UJK w Kielcach.

Głównym celem badawczym było przedstawienie modelu kształcenia nakierowanego na kształtowanie postaw przedsiębiorczych w dwóch ośrodkach akademickich w Polsce oraz ich ocena, w opinii studentów, w aspekcie dalszych możliwości kształcenia i podjęcia pracy zawodowej w warunkach gospodarki rynkowej.

Podstawą do przygotowania oraz podejmowania decyzji o zasadach, kierunkach i tempie perspektywicznego rozwoju kształcenia z podstaw przedsiębiorczości na rzecz społeczeństwa funkcjonującego w warunkach gospodarki rynkowej było przeprowadzenie badań diagnostycznych wśród studentów. Wybranie społeczeństwa młodego jako grupy docelowej uzasadnione jest rolą, którą odgrywa w życiu społecznym, a więc także w procesie budowania społeczeństwa innowacyjnego.

Celem badań było również poznanie i ocena:

- jak studenci geografii rozumieją pojęcie przedsiębiorczości,

- jakie postawy wobec przedsiębiorczości i przyszłej pracy ich cechują,

- jakie indywidualne cechy charakteru danej osoby sprzyjają decyzji np. o założeniu firmy,

- jaką rolę odgrywa przedsiębiorczość w kształtowaniu społeczeństwa funkcjonującego w warunkach gospodarki rynkowej.

Zaprezentowane w ankiecie pytania uporządkowano w następujące grupy tematyczne:

- pojęcie przedsiębiorczości i jej wymiary (proces, zespół cech),

- postawy i umiejętności interpersonalne człowieka przedsiębiorczego,

- rola osoby przedsiębiorczej w rozwoju społeczno-gospodarczym kraju w warunkach gospodarki rynkowej;

- ocena postaw studentów w zakresie przedsiębiorczości w warunkach gospodarki rynkowej i dalszych planów zawodowych. 
W badaniach diagnostycznych wzięło udział 128 mężczyzn i 142 kobiety. Największą liczbę mężczyzn stanowili studenci UP. Ankietowanymi byli studenci (270 osób): III roku studiów licencjackich $(71,4 \%)$ stacjonarnych i uzupełniających magisterskich $(28,6 \%)$. Respondenci biorący udział $\mathrm{w}$ ankiecie studiowali na jednej z dwóch uczelni: UP w Krakowie albo UJK w Kielcach. Blisko 65\% z nich pochodzi ze wsi i z miejscowości do 50 tys. mieszkańców. Pozostali badani (35\%) to studenci pochodzący z dużych miast, powyżej 500 tys. mieszkańców, i z miejscowości od 100 tys. do 500 tys. mieszkańców. W celu zebrania materiału empirycznego posłużono się kwestionariuszem ankiety. Przed rozpoczęciem badań przeprowadzono sondaż wstępny w celu przetestowania narzędzia badawczego. Ostateczna wersja kwestionariusza zawierała 12 pytań pogrupowanych w trzy grupy tematyczne. Pytania miały charakter zamknięty (7) i otwarty (5). Ankieta była anonimowa i przeprowadzona pod nadzorem pracowników uczelni. Pierwsza grupa tematyczna badań dotyczyła pojęcia przedsiębiorczości i jej dwóch wymiarów (procesu i zespołu cech osobowościowych człowieka przedsiębiorczego).

\section{Osoba przedsiębiorcza i jej cechy}

Według Nowej encyklopedii powszechnej PWN, ,przedsiębiorczość to zespół cech i zachowań właściwy przede wszystkim dla przedsiębiorców" (PWN, 1998, s. 361). Przedsiębiorczość rozumiana jest również jako, gotowość i zdolność podejmowania i rozwiązywania, w sposób twórczy i nowatorski nowych problemów, umiejętność wykorzystywania pojawiających się szans i okazji oraz elastyczne przystosowanie się do zmieniających się warunków funkcjonowania" (www.newtrader.pl).

W literaturze pojawiają się też cechy osoby przedsiębiorczej, takie jak: poczucie własnej wartości, pewność siebie, odpowiedzialność, upór w rozwiązywaniu problemów, skuteczność w działaniu, asertywność, umiejętność wyznaczania osiągalnych celów, optymizm, zdolność twórczego myślenia, gotowość do podejmowania ryzyka, umiejętność radzenia sobie z ewentualnymi niepowodzeniami, umiejętność nawiązywania dobrych kontaktów z ludźmi.

\section{Analiza wyników badawczych}

Studenci geografii najczęściej definiowali przedsiębiorczość jako: umiejętność pozyskiwania jak największych korzyści z dostępnych środków i zasobów (18,5\%), zdolność do planowania przedsięwzięć i kierowania nimi (13,5\%), umiejętność kreatywnego myślenia w sferze ekonomii (13,3\%), umiejętność zachowania się we współczesnym świecie w celu zapewnienia sobie dobrego poziomu życia (11,8\%), umiejętność radzenia sobie w życiu w różnych jego dziedzinach gospodarki rynkowej (12,3\%), umiejętność dostosowania się do nowych warunków przez kreowanie i wcielanie w życie własnych pomysłów (9,2\%). Ale były i takie sformułowania jak: „żeby dużo zarobić jak najmniejszym nakładem pracy” (9,3\%), „,przedsiębiorczość jest to przedmiot w szkole" (3,5\%), blisko 4,5\% badanych nie podało żadnej definicji przedsiębiorczości (ryc. 1).

Z przedstawionych definicji wynika, że studenci najprawdopodobniej zapamiętali definicję przedsiębiorczości ze szkoły ponadgimnazjalnej, ponieważ odpowiedzi były zbliżone do definicji w podręczniku przedsiębiorczości dla liceum.

Obecna rzeczywistość wymaga ciągłych zmian na lepsze, wyższej wydajności i efektywności, co można uzyskać przez przedsiębiorcze działania. Przedsiębiorczym jest więc człowiek zaradny, sprawny, skuteczny, a równocześnie myślący i odważny. Przedsiębiorczość wiąże się z pewnymi cechami. W literaturze pojawiają się też inne cechy osoby przedsiębiorczej, takie jak: poczucie własnej wartości, pewność siebie, odpowiedzialność, upór w rozwiązywaniu problemów, skuteczność w działaniu, asertywność, umiejętność wyznaczania osiągalnych 
celów, optymizm, zdolność twórczego myślenia, gotowość do podejmowania ryzyka oraz umiejętność radzenia sobie z ewentualnymi niepowodzeniami. Przedsiębiorczość człowieka wynika z jego cech osobowościowych, z zakresu wiedzy i umiejętności, dlatego też w kolejnym pytaniu zapytano respondentów o cechy osobowościowe człowieka przedsiębiorczego (ryc. 2). Studenci geografii najczęściej wskazywali na następujące cechy osobowości: pracowitość $(23,8 \%)$, pomysłowość $(16 \%)$, asertywność $(14,5 \%)$, komunikację interpersonalną (12,9\%), umiejętność analizowania sytuacji i ponoszenia ryzyka (7,6\%).

Badani wymienili i takie cechy, jak wyzysk człowieka przez człowieka (10,2\%), co może mieć związek z kryzysem gospodarczym w Europie i brakiem pracy, zwłaszcza wśród młodzieży wykształconej. Ankietowani w kolejnym pytaniu mieli za zadanie wskazać te cech

Ryc. 1. Pojęcie przedsiębiorczości wśród studentów geografii

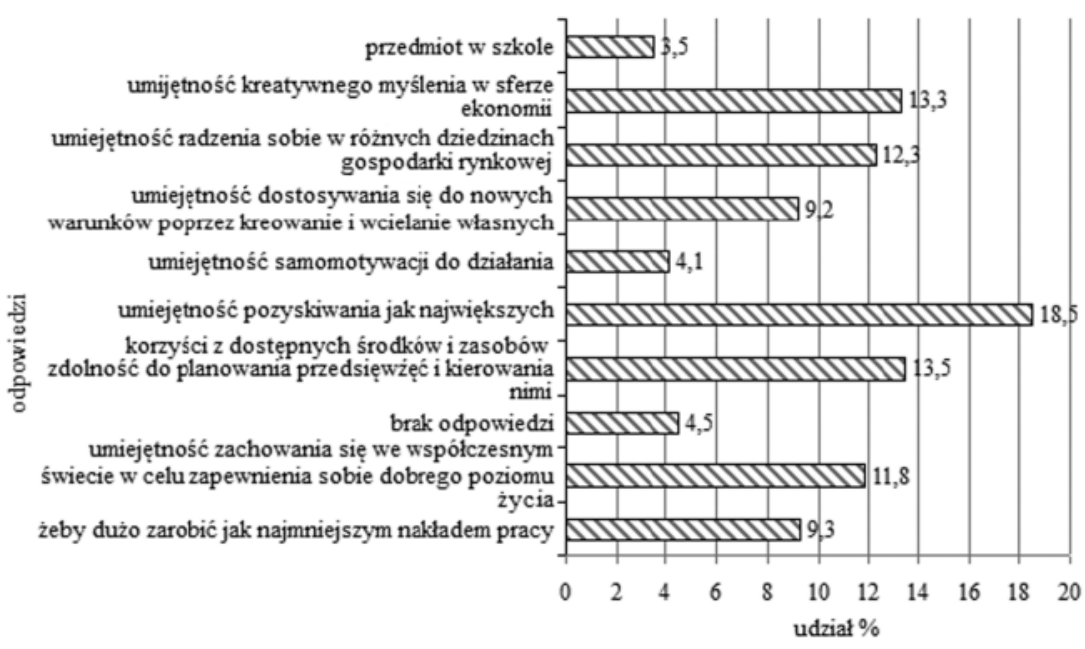

Zródło: opracowanie własne.

Ryc. 2. Cechy osobowości człowieka przedsiębiorczego

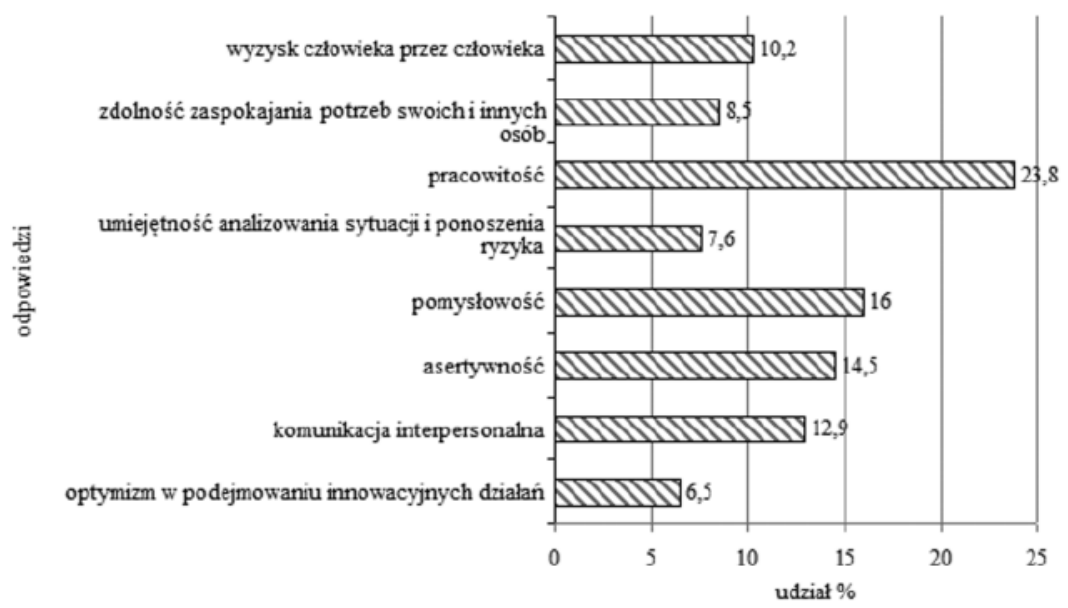

Źródło: opracowanie własne. 
człowieka przedsiębiorczego, które ich zdaniem są najważniejsze. Odpowiedzi były bardzo zróżnicowane. Największą rangę przypisano takim cechom, jak: pracowitość i wytrwałość (1 miejsce), komunikacja interpersonalna (2 miejsce), innowacyjność w działaniu (3 miejsce), pomysłowość (4 miejsce) oraz zdolność zaspokajania własnych potrzeb (5 miejsce). Najniżej oceniono: wiarę we własne zdolności (10 miejsce), zdolności organizatorskie (9 miejsce) i optymizm życiowy (8 miejsce), co może budzić pewien niepokój, ponieważ ankietowani to ludzie młodzi, którzy powinni wykazywać się większą wiarą w siebie i swoje umiejętności, ale zapewne takie opinie wynikają u młodych ludzi z braku stabilizacji na rynku pracy czy też zatrudniania ich na tzw. umowach śmieciowych (ryc. 3).

Ryc. 3. Ranking cech osobowościowych człowieka przedsiębiorczego

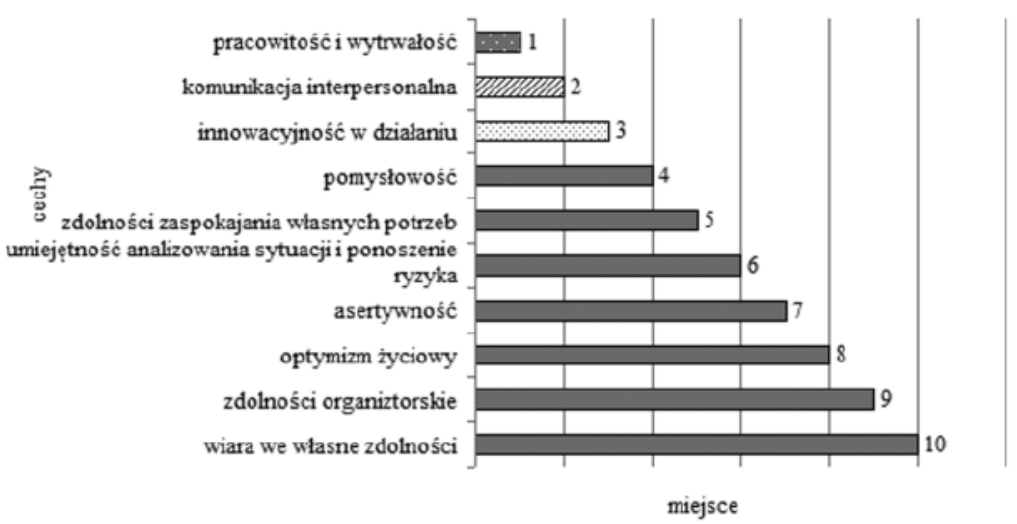

Źródło: opracowanie własne.

Respondenci mieli też określić, która $\mathrm{z}$ tych cech jest dla nich najważniejsza i uzasadnić dlaczego. Za najważniejsze cechy osobowościowe człowieka przedsiębiorczego uznali: pracowitość i wytrwałość, dążenie do celu, umiejętność podejmowania ryzyka i rozwiązywania problemów. Uzasadniali je następująco: ,pracowitość to najważniejsze cechy, ponieważ wywołują one u człowieka zapał do działań”, „człowiek powinien umieć sobie radzić z przeciwnościami”.

Coraz większe znaczenie dla człowieka przedsiębiorczego odgrywa wiedza. Człowiek przedsiębiorczy musi się uczyć przez całe życie. Ma to związek z coraz większą złożonością procesów technicznych, ekonomicznych i społecznych oraz wymaganiami pracodawcy. Przedsiębiorczość człowieka wynika także z praktycznego wykorzystywania wiedzy, co wiąże się z umiejętnością posługiwania się współczesną technologią informacyjną oraz umiejętnościami umysłowymi, takimi jak: efektywne słuchanie, logiczne rozumowanie i mówienie, twórcze myślenie, analizowanie, działanie, itp.

Osoba przedsiębiorcza działa sprawnie i racjonalnie, dokonuje zmian usprawniających i doskonalących jej działania. Z cechami człowieka przedsiębiorczego łączą się określone postawy i umiejętności, dlatego też poproszono studentów o wyjaśnienie pojęć: postawy, umiejętności interpersonalne. Nie najlepiej wśród studentów wypadło zdefiniowanie pojęcia postawy (ryc. 4).

Blisko $43 \%$ badanych nie udzieliła żadnej odpowiedzi, a tylko $57 \%$ podało definicję postaw. Najczęściej definiowano postawy jako: całokształt poglądów i zachowań danej osoby $(23,4 \%)$, sposób postępowania $(9,3 \%)$, kształtowanie postaw dialogu (8,9\%), godzenie własnego dobra z dobrem innych (8,5\%), kształtowanie odpowiedzialności za siebie i innych (6,9\%). Niestety tylko niespełna $66 \%$ respondentów podjęło się zdefiniowania pojęcia umiejętności interpersonalnych (ryc. 5). 
Ryc. 4. Znajomość terminu postawy w rozumieniu studentów

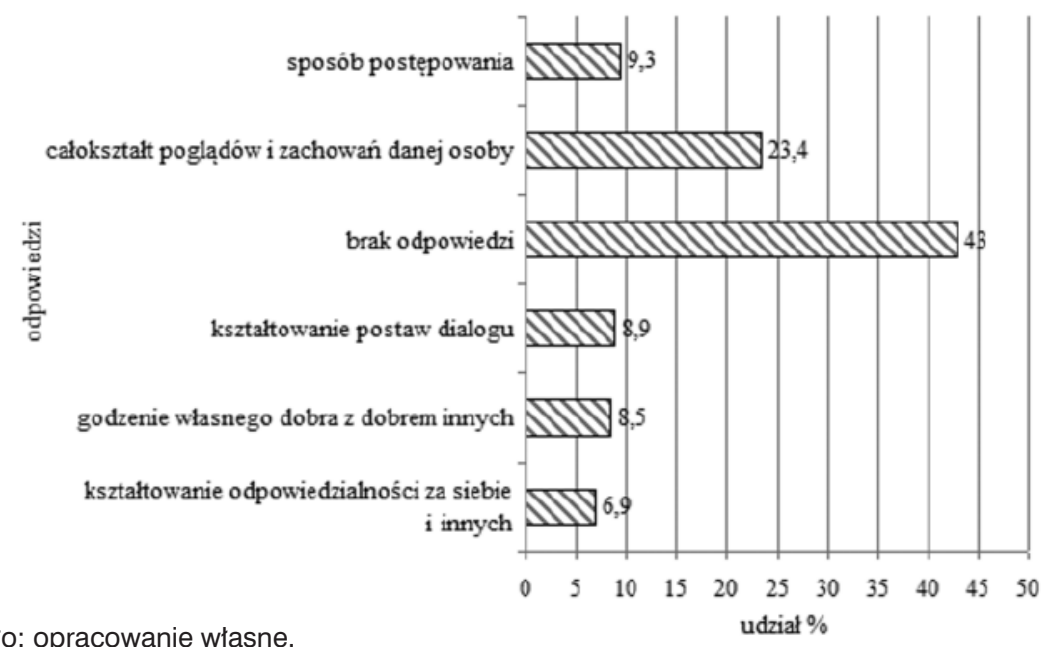

Źródło: opracowanie własne.

Ryc. 5. Pojęcie umiejętności interpersonalnych w opinii studentów

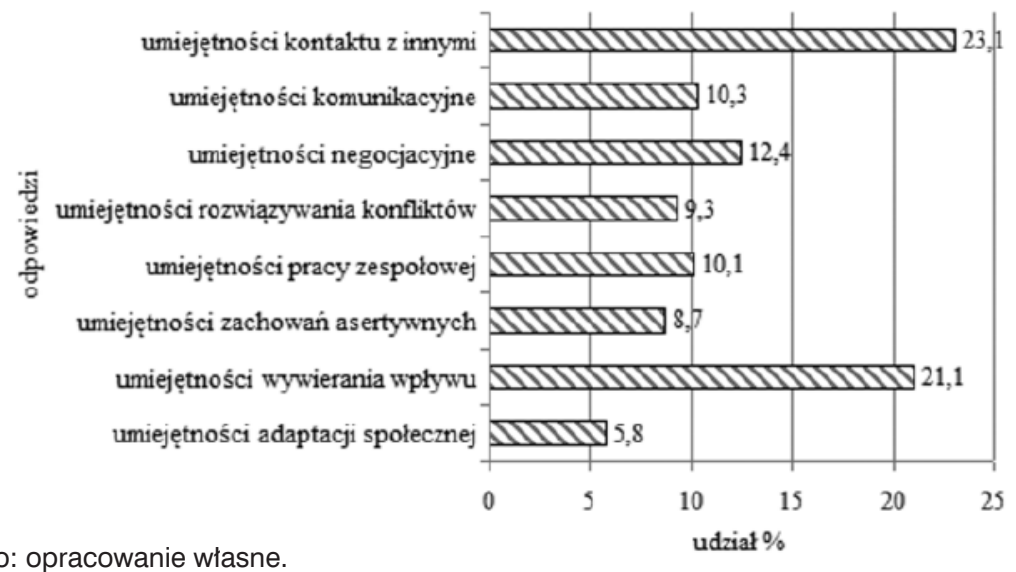

Źródło: opracowanie własne.

Spośród nich najczęściej studenci definiowali umiejętność jako: umiejętność kontaktu z innymi $(23,1 \%)$ i wywierania wpływu $(21,1 \%)$ oraz jako umiejętności negocjacyjne $(12,4 \%)$, umiejętność pracy w zespole (10,1\%), umiejętność rozwiązywania konfliktów (9,3\%).

Poproszono również badanych o wymienienie umiejętności interpersonalnych, które powinien mieć człowiek przedsiębiorczy. Respondenci najczęściej wskazywali na umiejętność: radzenia sobie w życiu, posługiwania się nowoczesnymi technologiami, znajomość języków, negocjacji, znalezienia dobrej pracy. Wymienienie postaw sprawiło studentom wiele problemów, być może wynikało to z niezrozumienia tego terminu. Tylko $43 \%$ badanych wymieniło postawy charakteryzujące człowieka przedsiębiorczego. Najczęściej respondenci wymieniali takie postawy, jak: wiara we własne siły, odpowiedzialność, empatia, uczciwość. Odwołując się do wymienionych postaw człowieka przedsiębiorczego, zapytano studentów, czy uważają się za człowieka przedsiębiorczego. Większość badanych wykazała brak zdecydowania, o czym świadczą odpowiedzi ,raczej tak” (39,7\%). Blisko 17\% ankietowanych udzieliła odpowiedzi „nie wiem”, 13,5\% odpowiedzi „tak”, a 29,3\% „raczej nie” (ryc. 6). 
Ryc. 6. Ocena własnej osoby jako człowieka przedsiębiorczego

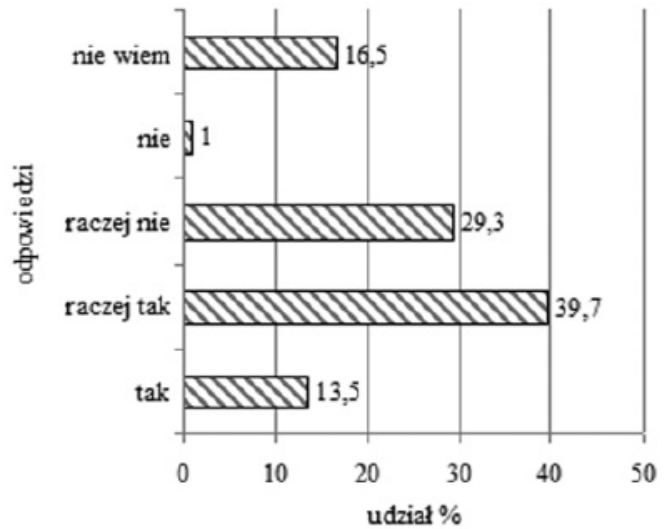

Źródło: opracowanie własne.

Blisko 39\% badanych podjęło się uzasadnienia swojego wyboru: zarządzanie swoim czasem i kapitałem, umiejętność negocjacji, dbanie o swoją przyszłość i przyszłość najbliższych, stabilizacja na rynku pracy, współpraca w pracy zespołowej. W sferze gospodarczej przedsiębiorczość pozwala na podjęcie i prowadzenie działalności lub na twórcze w niej uczestniczenie. To ludzie przedsiębiorczy podejmują i rozwijają działalność gospodarczą, a także wyróżniają się sukcesami. Przedsiębiorczość zwykle utożsamiana jest z dużą aktywnością, zaradnością, bystrością oraz systematycznością, a także pomysłowością. Współczesna gospodarka rynkowa szczególnie potrzebuje ludzi przedsiębiorczych, ze względu na dużą konkurencję na rynku pracy oraz stały postęp technologiczny, organizacyjny i ekonomiczny. W tym celu zapytano badanych o rolę, jaką powinna odgrywać osoba przedsiębiorcza w gospodarce. Badani za najważniejsze uznali: odkrywanie nowych rynków i produktów $(35,6 \%)$, poszukiwanie nowoczesnych technologii informacyjnych $(34,4 \%)$, reorganizowanie przedsiębiorstw (10\%), odkrywanie nowych zasobów (9\%), a 11\% badanych wskazało, że największy wpływ na przedsiębiorczość mają dopłaty w postaci różnych dotacji unijnych.

\section{Kształcenie studentów w zakresie przedsiębiorczości}

Ponieważ gospodarka rynkowa przebiega na wielu płaszczyznach, wśród których jedną z najważniejszych jest rynek pracy mający ścisły związek z wykształceniem i kompetencjami przyszłych pracowników, poproszono studentów o udzielenie odpowiedzi na pytanie dotyczące zmian zachodzących w kształceniu na wyższych uczelniach w zakresie przedsiębiorczości w warunkach gospodarki rynkowej. Odpowiedzi na to pytanie były zróżnicowane. Blisko połowa badanych widzi zmiany, które zachodzą w kształceniu studentów (33,5\%), a „raczej tak” odpowiedziało 16,2\%. Niestety w grupie badanych znaczna część nie dostrzega dostosowania kształcenia do potrzeb rynku i zapewne takich zmian w kształceniu studentów nie widzi. Dlatego blisko 41,4\% podało odpowiedź „nie” i „,raczej nie”, a 8,9\% zaznaczyło odpowiedź „nie wiem” (ryc. 7).

Jeśli chodzi o problematykę, którą studenci chętnie widzieliby w programie studiów, to związana jest ona głównie z: gospodarką rynkową, zarządzaniem własnym budżetem i kapitałem ludzkim, znajomością podstaw prawnych oraz z psychologią i pedagogiką pracy. Niespełna $23 \%$ badanych podało zagadnienia, które chciałoby poznać na studiach. Kolejne pytanie zawarte $\mathrm{w}$ ankiecie korespondowało z wcześniejszym i dotyczyło przedmiotów, na 
których studenci zdobyli wiedzę i umiejętności interpersonalne dotyczące przedsiębiorczości w warunkach gospodarki rynkowej. Przeważały odpowiedzi ogólnikowe i przeciwstawne, np. „na żadnym przedmiocie” (21,1\%), „na geografii społeczno-ekonomicznej” (29,4\%), „na gospodarce przestrzennej” (16,3\%), „na geografii regionalnej świata” (10,5\%), ,na przedmiocie z komunikacji interpersonalnej" (10,4\%). Przeszło 12\% ankietowanych nie udzieliło żadnej odpowiedzi na to pytanie (ryc. 8).

Ryc. 7. Zmiany zachodzące w kształceniu studentów w zakresie przedsiębiorczości

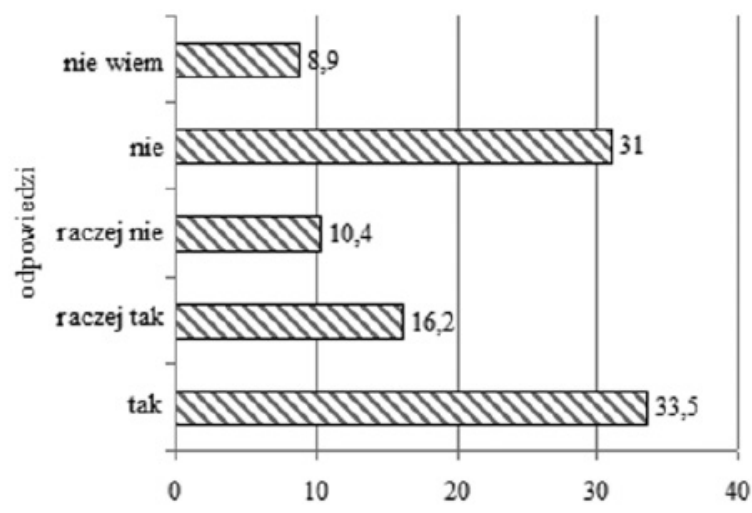

Źródło: opracowanie własne.

Ryc. 8. Przedmioty, w ramach których studenci zdobyli wiedzę i umiejętności w zakresie przedsiębiorczości

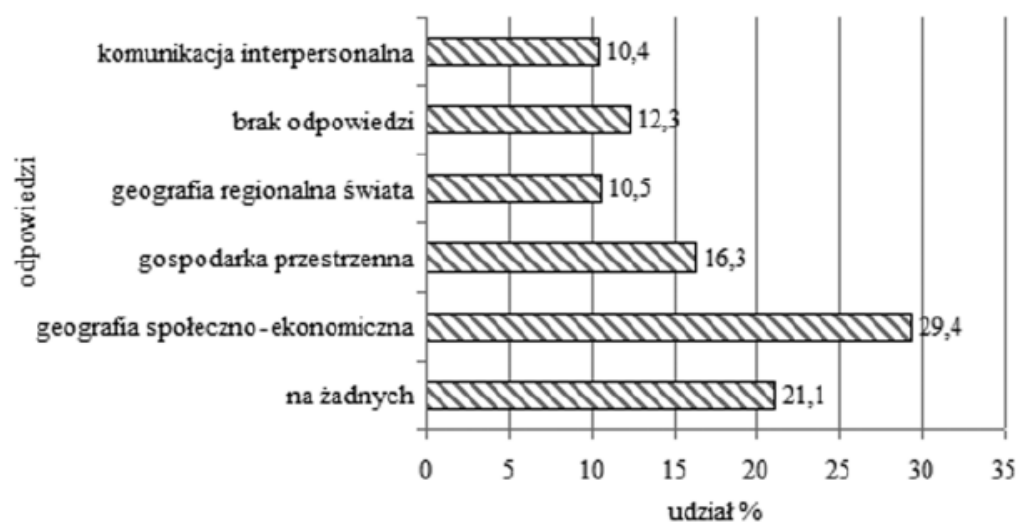

Źródło: opracowanie własne.

\section{Postawy i umiejętności interpersonalne}

W grupie ludzi łatwo można zaobserwować, że na daną sytuację każda z osób reaguje we właściwy sobie sposób. Zazwyczaj ten typ reakcji się powtarza - jest to postawa. W ujęciu psychologicznym przez postawę należy rozumieć pewne określone, stale powtarzające się schematy, według których osoba czuje, myśli i działa. Tak więc na postawy składają się emocje, myśli oraz predyspozycje do działania. Postawy mogą ulegać zmianom, np. pod wpływem osoby mającej autorytet lub cieszącej się zaufaniem otoczenia. Zmiana postaw może też nastąpić w wyniku długotrwałego procesu kształcenia. W kontaktach z innymi ludźmi, 
jeżeli pragnie się osiągnąć zamierzone cele, nie można być ani nadmiernie uległym, ani agresywnym. Powodzenie zapewnia postawa pośrednia, zwana asertywną. Praca zawodowa, realizacja ambitnych przedsięwzięć wymagają przejawiania inicjatywy i kreatywności. Aby być w zgodzie z własnym sumieniem i obowiązującymi normami, człowiek przedsiębiorczy powinien wykazywać się odpowiedzialnością i uczciwością.

Kolejne dwa pytania zawarte w ankiecie dotyczyły nabytych umiejętności i postaw na studiach w zakresie przedsiębiorczości w warunkach gospodarki rynkowej. Przeważały odpowiedzi: ,żadnych umiejętności interpersonalnych nie zdobyłem” $(60,4 \%) \mathrm{i}$,żadnych postaw nie osiągnąłem" (45,3\%). Tylko 28,4\% badanych wymieniło umiejętność komunikacji, którą nabyli na studiach, i negocjacji (11,2\%). Jeśli chodzi o postawy w zakresie przedsiębiorczości, studenci wskazywali na: tolerancję (31,4\%) i otwartość (23,3\%) (ryc. 9).

Ryc. 9. Umiejętności i postawy nabyte przez ankietowanych na studiach geograficznych

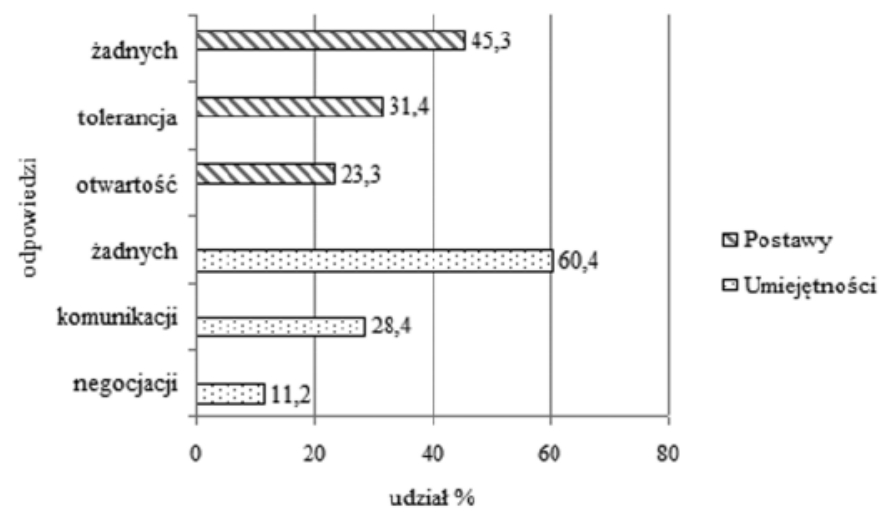

Źródło: opracowanie własne.

Studentów zapytano również o potrzebę zdobywania wiedzy z zakresu przedsiębiorczości oraz o to, jakich zagadnień powinna ta wiedza dotyczyć oraz jakie umiejętności komunikacji interpersonalnej chcieliby kształtować. Przeszło 77\% badanych widzi potrzebę kształcenia w zakresie przedsiębiorczości i komunikacji interpersonalnej, na co może wskazywać 69,3\% deklaracji na „tak” i 8,3\% na ,raczej tak”, tylko12,5\% nie miało zdania, a blisko 10\% nie widzi takiej potrzeby (ryc. 10).

Ryc. 10. Potrzeba kształcenia w zakresie przedsiębiorczości i komunikacji interpersonalnej w opinii studentów

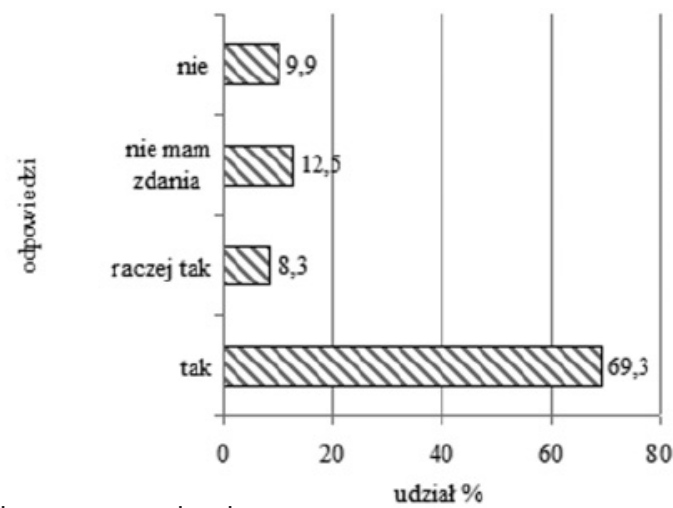

Źródło: opracowanie własne. 
W dalszej części tego pytania poproszono respondentów o podanie tych zagadnień, które powinny się znaleźć w programie studiów. Ponieważ było to pytanie otwarte, badani sporadycznie udzielali na nie odpowiedzi. Przeszło 33\% badanych nie udzieliło na to pytanie żadnej odpowiedzi. Najczęściej studenci widzą potrzebę zdobywania wiedzy na studiach geograficznych dotyczącą: podstaw prawnych i finansowych (25,4\%), zakładania własnej firmy (35\%), rynku pracy $(21 \%)$ wykorzystania wiedzy geograficznej w biznesie $(9 \%)$, wiedzy na temat ubezpieczeń $(9,6 \%)$.

Cechy typowe dla osobowości przedsiębiorczej ułatwiają nabycie określonych umiejętności przedsiębiorczych i interpersonalnych, np.: rozwiązywania problemów, szukania pomysłów, prowadzenia negocjacji, podejmowania decyzji. A wymienione cechy i umiejętności umożliwiają działania przedsiębiorcze takie, jak: wykorzystywanie możliwości, podejmowanie ryzyka, poszukiwanie możliwych i najlepszych rozwiązań, ponoszenie odpowiedzialności, odnalezienie się na rynku pracy. Dlatego też zapytano studentów o postawy, które chcieliby osiągnąć, by stać się człowiekiem przedsiębiorczym i aby móc sprostać wyzwaniom na rynku pracy w warunkach gospodarki rynkowej. Najczęściej badani wskazywali: pewność zatrudnienia, gdzie średnia wskazań wśród studentów UP w Krakowie wyniosła 2,9, a wśród studentów UJK z Kielc była znacznie wyższa i wynosiła 6,3 - co może świadczyć o tym, iż w małych miastach i na prowincji znacznie trudniej znaleźć pracę niż w dużym mieście, w którym widać stały rozwój społeczno-gospodarczy. Z kolei studenci studiujący w Krakowie, w mieście z tradycjami naukowymi, uniwersyteckimi i kulturowymi, za najważniejsze wskazali szacunek i uznanie wśród społeczeństwa: 5,9. Studenci chcieliby więcej zarabiać, by w ten sposób być bardziej niezależnymi, a to mogą osiągnąć przez realizowanie się w pracy, w której będą wykonywać ambitne i nowatorskie zdania (ryc. 11).

Ryc. 11. Postawy przedsiębiorcze studentów wobec przyszłej pracy

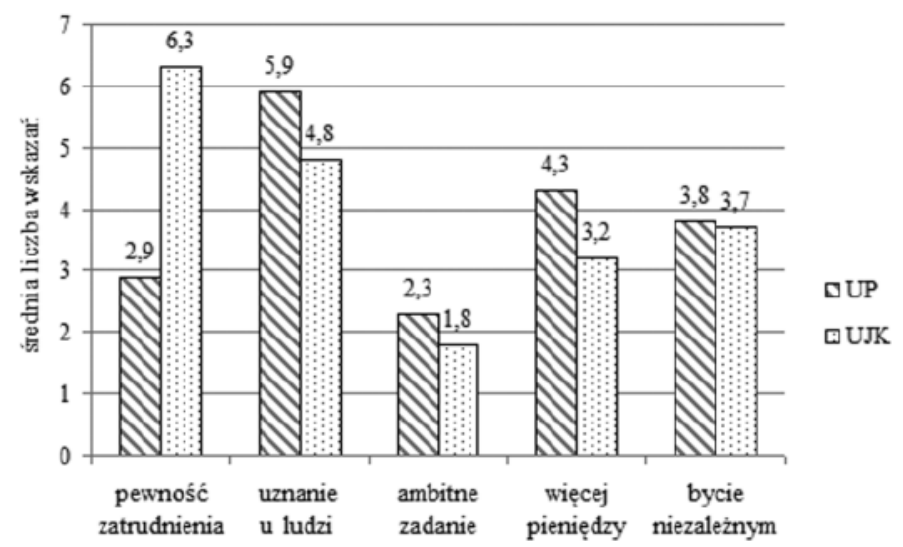

Źródło: opracowanie własne.

\section{Podsumowanie}

W krajach wysoko rozwiniętych gospodarczo zakończyła się era społeczeństwa technokratycznego i menedżerskiego, czyli takiego, które uprzywilejowuje wysoką technikę i zarządzanie. Rozpoczęła się natomiast era społeczeństwa przedsiębiorczego, w którym pierwszeństwo ma innowacja i samodzielność, rozwijające gospodarkę i życie społeczne. Nowatorskie zamierzenia pozwalają gromadzić kapitały na nowoczesną technologię, która niestety staje się coraz 
droższa. Stąd nowe wyzwania stojące przed kształceniem na poziomie wyższym. Ogromną rolę w tym kształceniu powinny odgrywać studia geograficzne, ale to wymaga zmian w programach studiów i podejściu nauczycieli akademickich do innowacji i zmieniającego się rynku pracy.

Osoby przedsiębiorcze są potrzebne w każdej pracy i we wszystkich dziedzinach ludzkiej aktywności, dlatego też studia wyższe powinny przygotowywać młode społeczeństwo do bycia przedsiębiorczym w warunkach gospodarki rynkowej. Niestety, jak wykazały badania, programy studiów mają niewiele wspólnego z przedsiębiorczością zarówno w zakresie wiedzy czy umiejętności, jak i postaw.

\section{Literatura \\ References}

Goleman, D. (1997). Inteligencja emocjonalna w praktyce, Poznań: Media Rodzina.

Komunikat Komisji dla Rady, (2006). Parlamentu Europejskiego, Europejskiego Komitetu SpołecznoEkonomicznego i Komitetu Regionów dotyczący rozbudzania ducha przedsiębiorczości poprzez edukację i kształcenie - Bruksela, s. 5.

Stanford, J. (2008). Economics for everyone: A short guide to the economics of capitalism, Pluto Press. Wiatrak, A.P. (2003). Pojęcie przedsiębiorczości, jej cele i rodzaje. W: Uwarunkowania rozwoju przedsiębiorczości - szanse i zagrożenia. Wydawnictwo Państwowej Wyższej Szkoły Zawodowej, Tarnobrzeg.

Wójtowicz, B. (2011). The students expectations and attitudes towards the role of the enterprise in terms of the European integration. W: Prace I Studia Geograficzne, 48, 18/2011, Warszawa: Wyd. UW, 64. http://www.newtrader.pl.

http://makroekonomia.wiedza.daboli.pl/gospodarka-rynkowa/.

Bożena Wójtowicz, dr hab., prof. UP, geograf, dydaktyk geografii, podróżnik. Zwiedziła większość krajów europejskich oraz Kubę, Meksyk, Indie, Nepal, Egipt, Maroko, Jordanię. Kierownik Zakładu Dydaktyki Geografii Instytutu Geografii Uniwersytetu Pedagogicznego im. Komisji Edukacji Narodowej w Krakowie. Opublikowała ponad 190 prac naukowych w kraju i zagranicą. Autorka monografii naukowej Geografia Rozwój Zrównoważony Edukacja Ekologiczna oraz współautorka i redaktor prac o charakterze monograficznym, m.in.: Przyroda województwa świętokrzyskiego, Funkcje turystyki i krajoznawstwa w strategii rozwojów regionów w Polsce, Turystyka i ekologia - rozbudzanie potrzeb poznawczych i świadomości społeczeństwa, Ksztatcenie i dokształcanie nauczycieli geografii w Polsce i w krajach Unii Europejskiej, Edukacyjne zajęcia terenowe w Świętokrzyskim Parku Narodowym. Współautorka podręczników szkolnych: Geografia. Krajobrazy Polski do klasy 4, Geografia Ziemia - nasza planeta do klasy 6, Przyroda do klasy 4 i 5 . Specjalistka z zakresu geografii, turystyki i rekreacji, dydaktyki geografii oraz ochrony środowiska.

Bożena Wójtowicz, PhD, a Professor at the Pedagogical University of Cracow.

A geographer, a geography teacher, a traveler. She visited most of the European countries, as well as Cuba, Mexico, India, Nepal, Egypt, Morocco, and Jordan. A Head of the Department of Geography, the Institute of Geography Teaching at 
the Pedagogical University of Cracow. She has published over 190 scientific papers in the country and abroad. The author of the monograph on Geography Sustainable Development Environmental Education. The co-author and editor of a monographic work, including Voivodship Nature, Features, tourism and sightseeing in the strategy of regional development in Poland, tourism and ecology - to foster the cognitive needs and public awareness, education and training of teachers of geography in Poland and in the European Union, Educational fieldwork in the Świętokrzyski National Park. Bożena Wojtowicz is also the co-author of the following textbooks: Geography. Polish Landscapes, Grade 4; Geography Earth - our planet, Grade 6; Nature, Grade 4 and 5. She is the specialist in the field of geography, tourism and recreation, teaching geography and the environment.

Adres/Address: Uniwersytet Pedagogiczny im. Komisji Edukacji Narodowej w Krakowie Instytut Geografii

ul. Podchorążych 2

30-840 Kraków, Polska

e-mail: boz.wojt@gmail.com 